\title{
Analysis of Steam Power Generators in Fulfilling Electricity Needs: A Case Study at PT Madubaru Yogyakarta, Indonesia
}

\author{
Danis Dwi Istiawan ${ }^{1}$, Ramadoni Syahputra ${ }^{* 1}$ and Karisma Trinanda Putra ${ }^{1}$ \\ ${ }^{1}$ Department of Electrical Engineering, Universitas Muhammadiyah Yogyakarta \\ Kampus Terpadu UMY, Jl Lingkar Selatan, Yogyakarta, Indonesia \\ *Corresponding author, e-mail: ramadoni@umy.ac.id
}

\begin{abstract}
This research was conducted to find out the amount of power produced by steam power generators and the amount of power needed for the operation of production motors in PT Madubaru Yogyakarta. This study also discusses the factors that support and inhibit the fulfillment of electric power in PT Madubaru Yogyakarta. From the results of the analysis that has been done, it can be seen that the power generated by the steam power generator at PT Madubaru Yogyakarta can meet the electricity needs of production motors in the factory. The power generated by the three steam generators at PT Madubaru amounts to 3,000 KW, while the power needed for the operation of production motors at the Milling Station, the Ketel Station, Central Factory Station, and Rear Factory Station is 2,313.54 KW. However, the production motor does not always turn on simultaneously, so the power needed is between 1,500 $\mathrm{KW}$ to 2,000 KW. The remaining power is used to anticipate an increase in electricity load.
\end{abstract}

Keywords: Steam power generator, Electricity needs, substation, peak load

\section{Introduction}

Electrical energy is an energy that cannot be separated from human life. Almost all aspects of life utilize electricity, both for domestic life and in the industrial world [1]-[3]. In the household, electricity is useful to help the daily survival of humans. Whereas in the industrial world, electricity is beneficial to help smooth and continuity in the production process [4].

Along with the development of science and technology, electricity demand is also increasing. Humans are required to be smarter in utilizing electrical energy and make developments to increase the capacity of electric power. So that power plants or generators emerge from various energy sources, such as water, steam, solar, wind, nuclear, and many other energy sources [5]-[7]. The increasing number of power plants is expected to increase the capacity of the electric power so that it can meet all the needs of the community.

In the industrial world, it certainly requires a plentiful supply of electricity to run all of its production machines [8]. Electricity supply from the National Electric Company (PLN) will only increase the budget to run all production machines. Such is the case with PT Madubaru, where a small portion of the electricity is sourced from the National Electric Company and most uses a steam power plant in the form of a steam power generator. The use of electricity sourced from steam generators at PT Madubaru is $80 \%$.

A steam generator is alternative energy used to help supply electricity to the Sugar Factory and Sepiritus Madukismo. From the description above, the researcher will conduct research on the analysis of steam power generators on meeting electricity needs at PT Madubaru Yogyakarta, Indonesia.

The purpose of this study is to determine the amount of power output generated from steam generators at PT Madubaru and determine the number of electrical power needs at PT Madubaru, by comparing the amount of power produced by steam power generators with the amount of power needed by production motors at PT Madubaru. Another objective is to analyze the factors that are supporting and inhibiting the fulfillment of electric power in PT Madubaru Yogyakarta, Indonesia.

Copyright $(2017$ Universitas Muhammadiyah Yogyakarta - All rights reserved 


\section{Literature Review}

Steam Power Plant is a generator that utilizes kinetic energy in the form of steam to produce electrical energy. The steam power plant has the main form of a generator that is connected to a turbine that is driven by kinetic energy from hot steam.

The following will be explained about research related to steam power generators on meeting electricity needs in a company, which are as follows. Nurmalita [9], a study entitled Energy Efficiency Analysis on the Steam Power Plant (PLTU) at PT Energi Alam Raya Semesta, was conducted. The research aims to find out how much the level of energy efficiency in the steam power plant system (PLTU) located at PT Energi Alam Raya Semesta and analyze the factors that affect the performance of each unit (component) in the PLTU system. Karaeng et al. [10] conducted a study entitled Boiler Performance Analysis at PLTU Unit 1 PT Semen Tonasa. The power plant at PT Semen Tonasa functions as a steam generator that will be used to drive turbines to produce electricity. the cause of the decline in the performance of boiler unit 1 of PT Semen Tonasa power plant. Hanzen Yauri et al. [11], a study entitled "Thermal Efficiency Study of Boilers in the Unit I Amurang Steam Power Plant," was conducted. At the Amurang power plant, the fuel used is coal, and the equipment to burn it is a boiler. Boilers or boilers are one of the devices in the thermal energy cycle that has the purpose of turning water into steam. This research was conducted to determine the thermal efficiency of boilers at the Amurang Unit 1 power plant based on operational data. The data collected is obtained from the Amurang power plant and then used to calculate the thermal efficiency of the boiler. Jamal et al. [12], have evaluated the performance of wind turbines with a double induction generator. The stator flux is oriented to the control vector, which is used to double the variable speed in the operation of the induction generator.

\section{II.1. Generator}

The steam power plant is a generator that utilizes kinetic energy from steam to produce electrical energy. The main form of this steam power plant is a generator that is connected to a turbine that is driven by kinetic energy from hot steam coming from coal, wood, and other fuels.
The generator is a device whose working principle is based on electromagnetic induction [13]. Michael Faraday first discovered the generator. A generator is a machine derived from kinetic energy that is converted into electrical energy. The kinetic energy contained in the generator can be obtained from waterfalls, winds, and so forth. Based on the current generated, generators can be divided into two, namely AC generators and DC generators. AC generators generate alternating current, whereas DC generators produce direct current. Both can be used for lighting and heating devices.

Generators are used in power plants such as hydropower, steam power, wind power, geothermal power, solar power, and others. As time goes by, synchronous generators are also found, so generators are inseparable from the world of electricity. A generator can also be defined as a system that generates electric power by inputting mechanical power. So the function of the generator is to change mechanical power into electric power, which has the following working principle. If the rotor is rotated, the winding of the wire will cut the magnetic forces at the magnetic pole, so that a voltage difference occurs, on this basis arises an electric current, current through the cable / the wire which is connected to the two ends of the sliding ring. On these rings, shift the brushes as the connecting terminal comes out.

The parts of the generator include the following:

\section{a. Rotor}

Rotors are rotating parts that have parts consisting of a shaft, a core, a coil, a sliding ring, and brushes. The rotor consists of two general parts, namely:

\section{1) Pole Core}

In the polar core, there is a shaft and rotor core that has a function as a path or path of magnetic flux generated by the field coil.

2) Medan Coils

In the field coil, there are two parts, namely the conductor as a path for the driving current and the isolated part. Insulation in this section must be excellent in terms of mechanical strength, resistance to high temperatures, and resistance to large centrifugal forces.

\section{b. Stator}

The stator is a part that does not rotate and has a part that consists of the stator frame. The stator is one of the main parts of the generator made of cast iron and is the home of all parts of the generator, the central pole and its windings, the supporting poles and their windings, the shaft bearings. The 
stationary part (Stator) consists of several parts, namely:

1) Stator Core

The stator core is in the form of laminated rings which are bound as tightly as possible to avoid eddy current losses. At the core of the stator, there are slots for placing conductors and for regulating the direction of the magnetic field.

2) Stator Winding

Stator section consisting of several conductor bars contained in slots and ends of the coil. Each slot is connected to get the induced voltage.

3) Stator flow

The stator groove is the part of the stator that acts as the place where the stator winding is placed.

\section{4) Stator's House}

Part of the stator is generally made of cast iron in a cylindrical shape. The back of the stator housing usually has fins as aids in the cooling process.

Power generator of steam power plant is shown in Figure 1. A generator as a part of electric power, which is very vital and expensive, so it needs to get reliable enough protection against interference that occurs. If there is a disturbance in the electrical circuit, the installation must be secured, and disturbed parts must be separated in the shortest possible time, it is useful to prevent or minimize the damage that can be caused by interference.

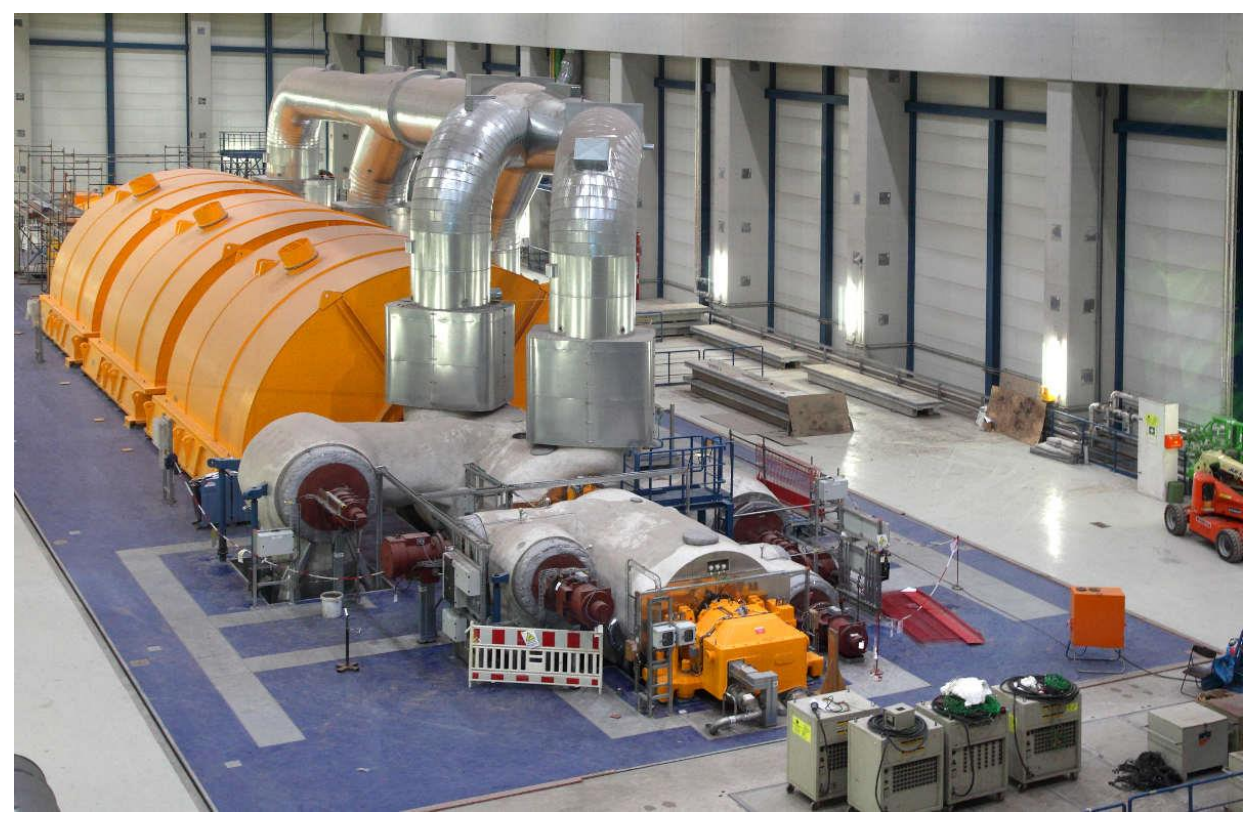

Figure 1. Power generator of steam power plant

The basic principle of alternating current generator uses Faraday's law. The law states that if a conductor is in a changing magnetic field, then the conductor will form a dynamic motion, where the rotor acts as a field coil (which produces a magnetic field) and will induce a stator as an anchor coil that will produce electrical energy. At the winding rotor is given a DC excitation current, which will create a magnetic field. This rotor is coupled with a rotating turbine and rotates to produce a rotating magnetic field. The rotating magnetic field will cut the anchor coil that is in the stator. With the change in magnetic flux at each time, then the anchor feed will flow the electromotive force induced by the rotor.

The amount of emf generated is expressed by:

$$
\mathrm{E}=\mathrm{C} \cdot \mathrm{n} . \varnothing
$$

where, $\mathrm{E}=$ electromotive force $($ Volt $), \mathrm{C}=$ engine constant, $\mathrm{n}=$ generator rotational speed, and $\varnothing=$ magnetic flux.

If a generator gets a load that exceeds its capacity, it will result in the generator not working even it will be damaged. To overcome the electricity needs or increasing load can be overcome by running another generator, which is then operated in parallel with the generator that has worked previously on the same electricity network. So if one of the generators suddenly has a breakdown, the generator can be stopped, and the load diverted to another generator. 
The connection of a generator with other generators in an interconnected network that is operated in parallel must meet the following requirements:

a. The effective value of the alternating current of the voltage must be the same.

b. The parallel generator voltage has the same waveform.

c. The frequency of the two generators or the frequency generator with the grid must be the same.

d. The phase sequence of the two generators must be the same.

\section{II.2. Steam Turbine}

The steam turbine is a driving force that converts potential energy into kinetic energy, and kinetic energy is then converted into mechanical energy in the form of turbine shaft rotation. The turbine shaft will be connected with a mechanism that is driven.
Steam turbines are commonly used in various fields of industry for electricity generation.

The working principle of a steam turbine is that steam enters the turbine through the nozzle. In the nozzle, the heat energy from steam is converted into kinetic energy, and the steam develops. The vapor pressure when exiting the nozzle is smaller than when entering the nozzle, but conversely, the velocity of the vapor exiting the nozzle is higher than when entering into the nozzle. The steam that emanates from the nozzle is directed to the turbine blade, which is shaped in an arc and installed around the turbine wheel. Steam flows through the gap is deflected towards the curve of the turbine blade. This change in steam velocity gives rise to pushing and then turning the wheels and turbine shaft. The typical steam turbine is shown in Figure 2.

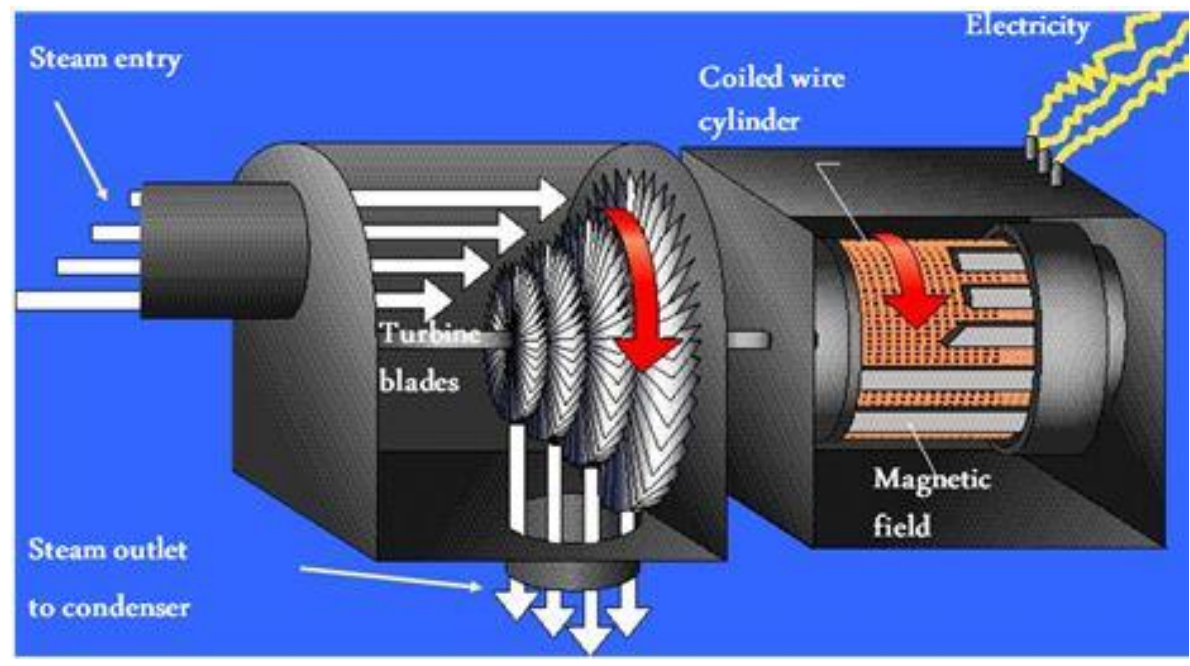

Figure 2. Typical steam turbine

The components in a steam turbine are as follows:

1) Casing; Serves as a cover for the central part of the turbine. The material used must be able to withstand high pressure and temperature.

2) Rotor; The rotor is the most essential part of rotating turbine construction, which functions as a blade fastener.

3) Nozzle; Tool to direct the steam pressure to turn the blade (blade) of the turbine.

4) Wheel; Is a collection of a series of road blades that are strung on a shaft rotor, bound by a shroud and made per section by the design of the manufacturer.
5) Gland Packing; As an insulator to withstand both leakages of steam and oil leaks.

6) Ringwheel Ring; Has the same function as gland packing, which is safety against oil leakage.

7) Pedestal Bearings; Is the position or resistance of the rotor shaft so that it can work efficiently.

8) Journal Bearing; Serves to hold the radial force of the rotor shaft (the force perpendicular to the rotor shaft).

9) Thrust Bearing; Serves to hold or to accept the axial rotor force (the force is parallel to the shaft).

10) Oil Deflector; Is part of the inner part that is mounted on the front and back of the bearing whose function is as a seal or sealant so that the lubricant 
does not occur cross water when the lubrication on the bearing operates

11) Cooler; Also called the Trust Dish as the foundation of the trust-pad.

12) Main Oil Pump; Serves to pump oil from the tank to be distributed to the rotating parts of the turbine.

\section{II.3. Electrical Power}

Electrical power is the amount of change in energy over time in the amount of voltage and current. Electric power can be divided into three, namely real power $(\mathrm{P})$, reactive power $(\mathrm{Q})$, and apparent power $(\mathrm{S})$.

a. Real power $\mathrm{P}$ is the actual power needed by electrical loads/household equipment. The unit of real power in watts $(\mathrm{W})$.

b. Reactive power $\mathrm{Q}$ is the power that arises because of the formation of a magnetic field under inductive loads. The unit of reactive power is reactive volt-ampere (VAR).

c. Pseudo power is the resultant between real power and reactive power. The unit of apparent power is volt-ampere (VA).

d. The power factor $(\operatorname{Cos} \varphi)$ is a multiplier constant with values 0 to 1 , which shows how much real power is absorbed by the resistive load of the apparent power that is at a total load.

\section{Methodology}

This research was conducted at PT. Madubaru Yogyakarta on September 23 to 25, 2017. This study was conducted to determine the amount of power generated by steam power generators in meeting the electricity needs of production motors located in PT Madubaru Yogyakarta. A steam turbine at PT Madubaru Yogyakarta, Indonesia, is shown in Figure 3.

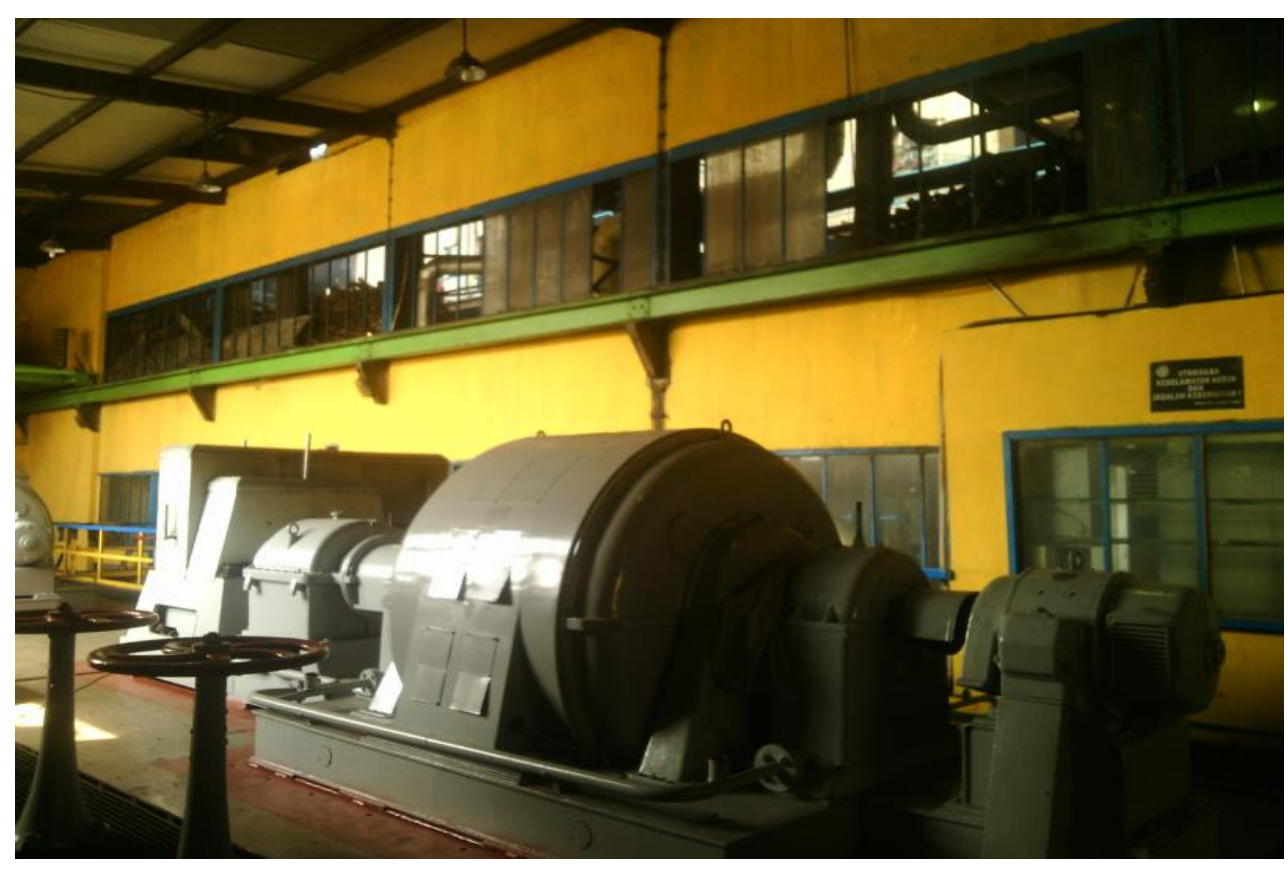

Figure 3. Steam turbine at PT Madubaru Yogyakarta, Indonesia

\section{Results and Discussion}

\section{IV.1. Steam Power Plant Data}

This research was conducted to retrieve predetermined primary data. The data that has been obtained is then analyzed to find out whether the power generated by the steam generator can meet the electricity needs at PT Madubaru. Besides, researchers also want to discuss further what factors are supporting and inhibiting the fulfillment of electric power at PT Madubaru.

Steam generator at PT Madubaru consists of 3 turbines; the three turbines are used to drive electric generators 1, 2, and 3. Also, steam generators are used to drive cane cutters 1 and 2, shredder hammer, roll mill 1 to 6 , and the water pump drive on steam boilers 1, 2, and 3. PT Madubaru has three generator-driven turbines. All three electricity generators will operate all during the milling season 
because it requires a large amount of electrical energy to drive all factory equipment. Meanwhile, when not milling the three generators, no one operates and only uses electricity supply from PLN. The use of a steam turbine as an electric generator drive is based on the following reasons:

a. More fuel-efficient, because a steam turbine does not need fuel directly.

b. The size is more straightforward when compared to other machines that produce the same power.

c. It has a high mechanical yield because, in the steam turbine, there are not many moving parts, and the movement is more regular because the steam turbine is not a translational movement.

d. Maintenance of a steam turbine is easy.

e. Especially for sugar factories, the use of steam turbines is very efficient because the steam released from the turbine is also used for the process of making sugar.

\section{IV.2. Types of Steam Generators at PT Madubaru}

The type of steam power generator used by PT Madubaru is a type of implant turbine in which the process of expansion of the working fluid (the pressure drop process) only occurs in a fixed blade or nozzle. Whereas in the pressure level, the turbine is a multilevel pressurized turbine (four pressure levels) with five rotor blades mounted on the rotor. In this case, steam flows through the first row of motors until the fourth pitcher, but before flowing to the next pitcher, the vapor flows through blades, which are united with the turbine housing or fixed housing and with multilevel valves.

The direction of axial vapor flow, wherein the vapor flows in a direction parallel to the turbine axis. The turbine is a type of backpressure turbines because the exhaust steam produced still has relatively high pressure and temperature so that the steam can be used for cooking, which is then condensed and sent back to the boiler. The installation of the turbine shaft is mounted horizontally and by using gears at PT. Madubaru, three steam turbines are driving electric generators with the same specific type and come from one company, namely: VEB. TURBINE FABRIC DRESDEN. EKM was originating from Germany. The turbine generator specifications are taken from the third turbine generator.

\section{Conclusions}

From the results of the analysis that has been done by comparing the power generated by the three steam power generators in PT. Madubaru Yogyakarta with the load needed for the operation of production machinery during the milling season, it can be seen that the power generated by the steam power generator at PT. Madubaru can meet the power requirements of production motors. The power generated from the three steam power generators in PT. Madubaru amounts to 3,000 KW. The power needed to operate production motors at the Milling Station, Kettle Station, Central Factory Station, and Rear Factory Station is 2,313.54 KW. The production motors do not turn on simultaneously, so the power needed is between $1,500 \mathrm{KW}$ to $2,000 \mathrm{KW}$ so that the remaining power is used to anticipate an increase in electric load or charge.

\section{Acknowledgements}

The authors express their deepest gratitude to the Universitas Muhammadiyah Yogyakarta for supporting this research activity.

\section{References}

[1] Syahputra, R., Soesanti, I., Ashari, M. (2016). Performance Enhancement of Distribution Network with DG Integration Using Modified PSO Algorithm. Journal of Electrical Systems (JES), 12(1), pp. 1-19.

[2] Syahputra, R., Robandi, I., Ashari, M. (2015). Performance Improvement of Radial Distribution Network with Distributed Generation Integration Using Extended Particle Swarm Optimization Algorithm. International Review of Electrical Engineering (IREE), 10(2). pp. 293-304.

[3] Syahputra, R., Robandi, I., Ashari, M. (2014). Optimization of Distribution Network Configuration with Integration of Distributed Energy Resources Using Extended Fuzzy Multi-objective Method. International Review of Electrical Engineering (IREE), 9(3), pp. 629-639.

[4] Syahputra, R., Robandi, I., Ashari, M. (2015). Reconfiguration of Distribution Network with DER Integration Using PSO Algorithm. TELKOMNIKA, 13(3). pp. 759-766.

[5] Syahputra, R., Soesanti, I. (2016). DFIG Control Scheme of Wind Power Using ANFIS Method in Electrical Power Grid System. International Journal of Applied Engineering Research (IJAER), 11(7), pp. 5256-5262.

[6] Syahputra, R., Soesanti, I. (2015). Power System Stabilizer model based on Fuzzy-PSO for improving 
power system stability. 2015 International Conference on Advanced Mechatronics, Intelligent Manufacture, and Industrial Automation (ICAMIMIA), Surabaya, 15-17 Oct. 2015 pp. 121126.

[7] Syahputra, R., Soesanti, I. (2016). "Power System Stabilizer Model Using Artificial Immune System for Power System Controlling”. International Journal of Applied Engineering Research (IJAER), 11(18), pp. 9269-9278.

[8] Syahputra, R. (2016). "Transmisi dan Distribusi Tenaga Listrik". Yogyakarta : LP3M UMY Yogyakarta.

[9] Nurmalita (2012), “Analisis Efisiensi Energy pada Pembangkit Listrik Tenaga Uap (PLTU) PT. Energi Alamraya Semesta di Kabupaten Nagan Raya Nanggroe Aceh Darussalam", Thesis, Institit Pertanian Bogor.

[10] Karaeng, C.T., Iswandi, Firman, Nuzul, M., (2012), "Analisis Kinerja Boiler pada PLTU Unit 1 PT. Semen Tonasa, Makassar", PNUP.

[11] Hanzen Yauri. K, Hardi. G, Benny. M, (2015), "Kajian Efisiensi Termal Dari Boiler Di Pembangkit Listrik Tenaga Uap Amurang Unit I", Jurnal Online Poros Teknik Mesin, 4(2).

[12] Jamal, A., Suripto, S., Syahputra, R., (2016), Performance Evaluation of Wind Turbine with Doubly-Fed Induction Generator, International Journal of Applied Engineering Research (IJAER), Vol. 11, No. 7.

[13] Kadir, A. (1996), "Pembangkit Tenaga Listrik", Universitas Indonesia, Jakarta.

\section{Authors' information}

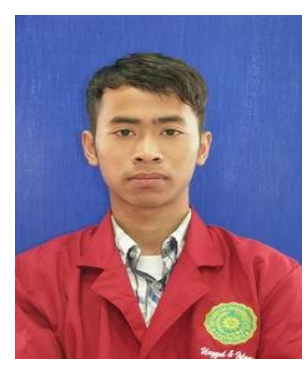

Danis Dwi Istiawan Received B.Sc. degree from Department of Electrical Engineering, Universitas Muhammadiyah Yogyakarta, Yogyakarta, Indonesia in 2017. His research interests are in operation of power system and power system planning.

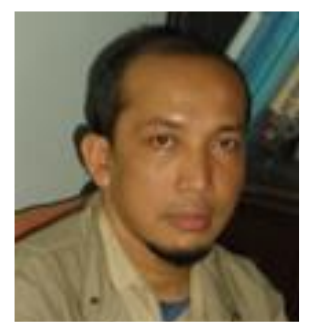

Ramadoni Syahputra received B.Sc. degree from Institut Teknologi Medan in 1998, M.Eng. degree from Department of Electrical Engineering, Universitas Gadjah Mada, Yogyakarta, Indonesia in 2002, and Ph.D degree at the Department of Electrical Engineering, Faculty of Industrial Technology, Institut Teknologi Sepuluh Nopember, Surabaya, Indonesia in 2015. Dr. Ramadoni Syahputra is a Lecturer in Department of Electrical Engineering, Faculty of Engineering, Universitas Muhammadiyah Yogyakarta, Indonesia. His research interests are in computational of power system, artificial intelligence in power system, power system control, the application of fuzzy logic in power system, optimization, distributed energy resources, and renewable energy.

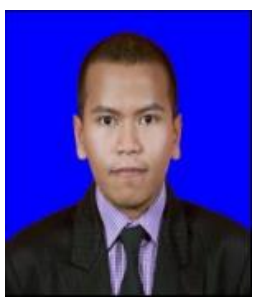

Karisma T. Putra, born in Bondowoso on June 19, 1990. He graduated from elementary to senior high school in Bondowoso until 2008. Studied bachelor degree program in Surabaya, precisely in Electronics Engineering Polytechnic Institute of Surabaya (EEPIS) until 2012. He got scholarship program to continue master degree in Institut Teknologi Sepuluh Nopember (ITS) Surabaya. Now, he is a lecturer at electrical engineering, faculty of engineering, Universitas Muhammadiyah Yogyakarta. The main focus of research is the intelligent systems and controls. He engaged in joint research related to the development of food commodity tracking systems and integrated intelligent systems. He was involved in several competitions in developing smart devices. Pursue the field of electronics and software development since college. Mr. Putra joined in Indonesian's engineer union organization (PII) in 2016. Mr. Putra is also active in writing publications on IEEE society. 